\title{
DEPENDÊNCIA DAS RENDAS PETROLÍFERAS NOS MUNÍCIPIOS DO RJ
}

\author{
DEPENDENCY ON THE INCOMES FROM OIL AND GAS IN THE MUNICIPALITIES OF THE STATE OF RIO DE JANEIRO
}

\section{RESUMO}

O objetivo deste capítulo é analisar a relevância das rendas do petróleo e gás natural para os municípios do Rio de Janeiro e as consequências dessa dependência. Propõe-se evidenciar a dependência que os orçamentos municipais apresentam das rendas petrolíferas e os riscos associados à dependência de recursos finitos que tem preços definidos com base em cotação no mercado internacional, portanto, sujeitos a elevada incerteza e extrema volatilidade. 0 levantamento do grau de dependência dos municípios teve por objetivo alertar para os riscos associados à dependência dos orçamentos a esses recursos. Além das mudanças na produção e exploração, ditadas pela lógica da atividade industrial petrolífera, também as mudanças na legislação que rege a distribuição das rendas entre os entes federativos, ampliam a incerteza quanto ao recebimento das rendas geradas e potencializam os riscos para os governos locais. A conclusão desse texto aponta para uma expectativa de continuidade na priorização de investimentos das empresas petrolíferas no pré-sal da Bacia de Santos nos próximos anos, em detrimento de áreas produtoras tradicionais da Bacia de Campos, em função da elevada produtividade daqueles campos. Assim, os municípios das regiões geograficamente confrontantes deverão seguir sendo afetados, tanto em seus orçamentos como nas indústrias petrolíferas e fornecedores de bens e serviços em seus territórios e seus impactos sobre o emprego e a renda.

Palavras-chave: Rendas Petrolíferas. Royalties. Mudanças Legislativas. Recursos Naturais. Impactos nas Finanças públicas municipais. Rio de Janeiro. Brasil.

\section{ABSTRACT}

This chapter analyzes the importance of the income generated from oil and gas industries to municipalities in the state of Rio de Janeiro and the consequences of this dependency. The importance of the taxes, royalties and other revenues generated by this industry to the municipal budgets show a great exposure to an extremely volatile situation derived from the dependency of finite resources whose price is defined by the flotation of international markets. The effort of demonstrating the dependency of these municipalities to these taxes and royalties aims to flag the risks of having such a profile of income that is prone to variation, not only as a consequence of the fluctuation in the production or of the international price, it also has to do with changes in the legislation that rules on the matter of the distribution of the royalties and taxes among the federative entities. It is safe to say that the dependency in these terms strengthens the unpredictability of local government's budgets and, consequentially, weakens long-term policy elaboration and execution. The main conclusion of this text is that this instable scenario is aggravated by the expectation of incremental investment in the oil and gas exploitation in pre-sal fields in the Santos Bay (SP) due to the expectation of higher productivity of these fields. In the possibility of confirming this scenario, the municipalities that confront the sea-area of the Campos Bay production fields will keep on being affected in their budget and in the diffuse investments, employment and income that the industry brings with it.

Keywords: Oil and Gas Income. Royalties. Legislative changes. Natural resources. Impacts on local public finance. Rio de Janeiro. Brazil.

\author{
Ana Maria Bretas ${ }^{a}$ \\ Fernanda Greco Laureano ${ }^{a}$ \\ Nina Quintanilha ${ }^{a}$ \\ Paula Nazareth ${ }^{\text {a }}$ \\ a Tribunal de Contas do Estado do Rio de \\ Janeiro (TCE-RJ), Rio de Janeiro, RJ, Brasil
}

DOI: $10.12957 /$ geouerj.2019.48410

Correpondência: paulanazareth@gmail.com

Recebido em: 22 set. 2019

Revisado em: 26 out. 2019

Aceito em: $11 \mathrm{dez} .2019$ 


\section{INTRODUÇÃO}

O objetivo deste artigo é analisar a relevância das rendas do petróleo e gás natural para os orçamentos públicos dos municípios brasileiros, reconhecendo que estas constituem importante fonte de receitas, senão para todos, certamente para um número considerável dos municípios do país. Entre estes, sobressaem, pela magnitude dos valores recebidos, os municípios do RJ.

Visando melhor situar o caso dos municípios fluminenses, propõe-se evidenciar a dependência que os orçamentos municipais apresentam das rendas petrolíferas e os riscos associados à dependência de recursos finitos, não renováveis, e que tem preços definidos com base em cotação no mercado internacional, portanto, sujeitos a elevada incerteza e extrema volatilidade. ${ }^{1}$

A apropriação dos recursos financeiros gerados pelas atividades petrolíferas por estados e municípios está inserida na lógica da descentralização de receitas que é característica da federação brasileira - justificada, em contrapartida, pelas inúmeras atribuições dos governos subnacionais, em especial, dos municípios que são os principais entes executores das políticas públicas em âmbito nacional.

Apesar do aumento da participação dos municípios na receita disponível nacional (soma das receitas tributárias das três esferas e posterior divisão por meio das transferências intergovernamentais) nos últimos anos $^{2}$, observa-se, em grande parte das cidades, ausência de condições institucionais adequadas para o planejamento e gestão do território e, principalmente, de capacidade de financiamento.

De fato, o acesso ao crédito de longo prazo, necessário para investimentos relacionados aos projetos de infraestrutura e à gestão urbana, é restrito e os governos locais possuem limitada capacidade de autofinanciamento por meio dos impostos de competência municipal, já que as bases tributárias definidas constitucionalmente são limitadas e não lhes asseguram a plena autonomia financeira. ${ }^{3}$

Diante dessa realidade, a transferência de recursos financeiros do governo federal e dos governos estaduais para os municípios torna-se crucial para ajustar vertical e horizontalmente a capacidade de gasto, especialmente em um cenário de crise fiscal, em que os recursos para investimentos e provisão de serviços públicos são escassos ou inexistentes.

\footnotetext{
1 Para uma análise dos fatores de influência das rendas ver Nazareth, Araújo e Oliveira (2018).

2 Afonso e Castro (2017) estimam que a participação dos municípios dobrou de 10\% para $20 \%$ do total da receita disponível nacional desde meados da década de 1980.

3 Nazareth (2017).
} 
A atual crise fiscal, no entanto, acentuou falhas já conhecidas do sistema de transferências intergovernamentais, que não vinha cumprindo com o objetivo de equalizar a capacidade horizontal de gasto como apontado na literatura ${ }^{4}$, falhas essas que passam a estar no centro de acirradas disputas.

Um exame dos dados relativos às realidades socioeconômicas dos municípios brasileiros, ainda que superficial, evidencia que depois das transferências permanecem expressivas disparidades de receita disponível entre municípios, até vizinhos, revelando que o sistema de transferências - em especial, das que buscam promover a equalização da capacidade de gasto (caso dos fundos de participação dos municípios) não alcança seus objetivos.

Por não serem coordenadas e obedecerem a critérios distintos de rateio, em muitos casos as transferências contribuem para aprofundar as desigualdades regionais, comprometendo a capacidade financeira dos governos locais de assegurar o desenvolvimento sustentável, com condições de vida adequadas para a população, acesso a moradia, bens e serviços públicos de qualidade, minimizando impactos ambientais. $^{5}$

As consequências da inadequação da estrutura de financiamento à atual configuração de encargos incluem o acirramento das disputas por recursos (guerra fiscal) e as tensões federativas, que inviabilizam reformar as regras do sistema tributário e de repartição dos recursos, e principalmente a construção de um modelo de Federação cooperativo, ameaçando a sustentabilidade do sistema fiscal brasileiro. ${ }^{6}$

As receitas provenientes da exploração do petróleo e gás natural incluem-se nesse quadro: por um lado, sua distribuição entre os entes acentua desigualdades horizontais em virtude das regras de rateio; por outro, a disputa pela distribuição de recursos está no centro das discussões da revisão do pacto federativo.

Para melhor abordar o tema, contudo, é importante considerar dois fatos recentes de grande relevância que vêm modificando e pautando o debate sobre a distribuição das rendas petrolíferas no Brasil, ambos relacionados às descobertas de jazidas gigantes no horizonte geológico do pré-sal na década de 2000.

O primeiro fato é a mudança observada na área da produção de petróleo e gás natural advinda do progressivo deslocamento de capitais, estruturas e investimentos na direção principalmente da Bacia de Santos, mais ao sul da costa brasileira, buscando a maior rentabilidade proporcionada pela exploração no présal.

\footnotetext{
${ }^{4}$ Ver Santos e Nazareth (2018), Nazareth (2017), Alencar e Gobetti (2008) e Prado (2001) para a discussão do sistema de transferências e dos desafios do financiamento municipal no contexto de descentralização do país.

5 Prado (2001, p. 54-55) chama a atenção para o fato de que os fluxos orientados para a provisão de bens específicos (como o FUNDEF e o SUS) teriam lógicas internas mais consistentes; o problema estaria nos fluxos voltados para prover a "equalização da capacidade orçamentária de gasto dos GSN, ou seja, os Sistemas de Fundos de Participação e cota-parte" (Nazareth, 2007:309). ${ }^{6}$ Nazareth (2007).
} 
A crescente produção nessa área vem gerando rendas expressivas para o governo federal e para estados e municípios que possuem confrontação geográfica com campos dessa bacia, ao mesmo tempo em que vem implicando em redução de investimentos na exploração dos campos maduros do pós-sal da Bacia de Campos.

Por duas décadas, essas atividades produziram rendas extraordinárias que beneficiaram de forma preponderante o Estado do Rio de Janeiro e municípios das regiões norte fluminense e das bacias litorâneas, confrontantes com os campos marítimos dessa bacia, que vêm perdendo protagonismo no recebimento das rendas ${ }^{7}$.

Esse ponto remete ao segundo fato relevante: o questionamento, por parte de estados e municípios brasileiros que não são considerados "produtores", dos critérios que presidem a distribuição das rendas petrolíferas desde a década de 1980 (início da exploração do petróleo no mar) e a luta travada, no campo político e da legislação, por novas regras de distribuição.

A lei aprovada no Congresso Nacional em 2012, que trazia mudança dos critérios, teve seus efeitos suspensos em 2013 pelo Supremo Tribunal Federal (STF), atendendo a ações diretas de inconstitucionalidade ajuizadas por alguns estados produtores, insatisfeitos com as consequências do novo marco regulatório que, além da mudança da distribuição, instituiu os regimes de partilha de produção e cessão onerosa e a criação da Pré-Sal Petróleo (PPSA). ${ }^{8}$

Se aprovadas definitivamente as novas regras de rateio, as parcelas dos fundos especiais destinados a todos os estados e municípios brasileiros e do Fundo Social da União deverão aumentar, tanto no modelo de partilha como no de concessão, implicando a substituição do caráter compensatório que preside atualmente a distribuição das rendas (previsto no art. 20 da Constituição federal), pelo viés redistributivo. ${ }^{9}$

Em meio ao cenário de crise fiscal e revisão do pacto federativo definido em 1988, em que se trava importante disputa pelas rendas do petróleo e de outras fontes, se avolumam os desafios impostos aos governos locais - promover o desenvolvimento humano nas cidades, por meio de políticas públicas inclusivas, em um contexto democrático, em um país federativo de grandes dimensões, com três níveis de governo com elevada autonomia, sem instâncias adequadas de articulação e coordenação.

Agravando o contexto de disputa, as rendas petrolíferas cresceram em 2018. Segundo Afonso e Castro (2019), a expansão vigorosa da carga tributária bruta brasileira entre 2017 e 2018 (que teria alcançado 1,33 "ponto" do PIB), resultou de fatores ordinários - ligados à arrecadação dos principais tributos do sistema

\footnotetext{
${ }^{7}$ As rendas são recebidas pelos entes fluminenses pelo fato de serem considerados, de acordo com a lógica geográfica que atualmente preside a distribuição, como produtores de petróleo e gás natural.

8 Ver Nazareth, Araújo e Salles (2011) e Nazareth, Araújo e Oliveira (2018) para análises das mudanças do marco legal.

${ }^{9}$ A legislação aprovada também alterou a aplicação dessas rendas, direcionando grande parte dos recursos às áreas de saúde e educação (Nazareth, Araújo e Oliveira, 2018).
} 
tributário (crescimento que seria estrutural, fundado, principalmente, no desempenho do IR, do Cofins/PIS e do ICMS) - e extraordinários, destacando-se as receitas de royalties do petróleo, com crescimento nominal de mais de $50 \%$ relativamente ao ano anterior. ${ }^{10}$

Em condições objetivas de elevada incerteza quanto à continuidade do recebimento dessas receitas, que impactam significativamente orçamentos de alguns dos municípios das regiões consideradas produtoras, torna-se urgente a discussão, fundamentada em evidências, tanto da dependência dos recursos quanto das políticas públicas em execução e seus impactos nos territórios.

Considerando a possibilidade concreta de perda financeira significativa para os municípios fluminenses em razão do peso das rendas petrolíferas em seus orçamentos, o acompanhamento e a necessária revisão das políticas e seus efeitos, com correção de rumos, são cruciais para que os governos locais proponham e implementem políticas de consequências efetivas, voltadas para o enfrentamento dos desafios trazidos pela chamada "maldição dos recursos naturais", caracterizada pela "relação negativa entre abundância de recursos naturais e nível de desenvolvimento econômico" (Piquet et al, 2017:203).

As rendas petrolíferas: contexto atual e o debate acerca da distribuição

Em 2018, de acordo com Afonso e Castro (2019), as transferências da União para os municípios, principalmente pelo FPM, totalizaram $\mathrm{R} \$ 129$ bilhões (1,90\% do PIB), enquanto os estados transferiram para os municípios cerca de $\mathrm{R} \$ 178$ bilhões (2,6\% do PIB, mais da metade foi oriundo da cota parte do ICMS).

Dessa forma, os municípios tiveram expressivo ganho de receita: de uma arrecadação direta (receita diretamente arrecadada) equivalente a 2,52\% do PIB, para uma receita disponível, depois das transferências, de $7,01 \%$ do PIB.

Nos municípios do Rio de Janeiro, não é diferente: em 2018, as transferências correntes e de capital responderam por $53 \%$ do total da receita bruta dos municípios, enquanto a receita tributária correspondeu a $28 \%$ (dados de 2018 do Siconfi, STN).

Os municípios fluminenses, contudo, tem uma peculiaridade, já mencionada. Em função da elevada concentração das reservas provadas de petróleo e gás natural no estado ${ }^{11}$ e do aumento da produção

\footnotetext{
10 Afonso e Castro (2019). Estimativa da carga tributária bruta de 2018, elaborada pela Secretaria do Tesouro Nacional, indica crescimento da arrecadação bruta das três esferas, que alcançou 33.58\% do PIB em 2018. Por essa estimativa, a arrecadação dos municípios cresceu 0.20 p.p do PIB entre 2017 e 2018, com destaque para o ISS e o IPTU. Disponível em: https://tinyurl.com/y3pxwvh9.

11 As reservas provadas de petróleo e gás do RJ representavam $83 \%$ e $65 \%$ do total nacional, respectivamente, em dezembro de 2018, segundo a ANP. (Disponível em: https://bit.ly/36kGaqw).
} 
petrolífera brasileira, nos últimos anos as receitas da compensação financeira paga pelas empresas concessionárias passaram a constituir importante e crescente fonte de recursos para o governo estadual e dos municípios fluminenses, com forte impacto positivo em suas finanças, embora voláteis pela própria natureza e origem desses recursos como se analisará, ilustrado na Figura 1 a seguir. ${ }^{12}$

Figura 1. Participação \% das receitas de Royalties e PE na receita dos Municípios do RJ - 2000/2018 Fonte: ANP, Sigfis (TCE-RJ) e SIOPS (MS).

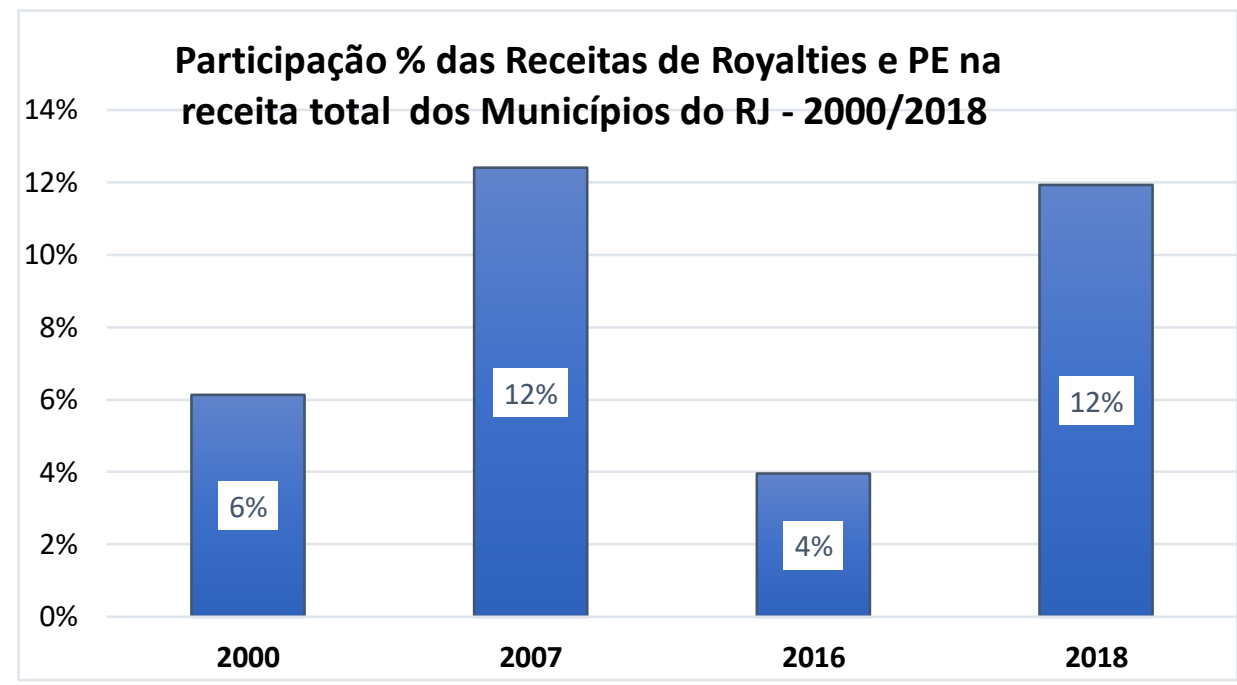

Como se observa na Figura 1, desde 2000, as receitas de royalties e participações especiais passaram a representar parcela cada vez mais importante das receitas dos municípios do RJ, puxadas, sobretudo, pela alta na produção dos poços da Bacia de Campos, com crescente e significativo impacto nos orçamentos.

De um percentual de 6\% em 2000, o peso dos recursos dobrou até 2007 (pré-crise), quando chegou a 12\% das receitas totais, e seguiu crescendo até 2014. A partir daí, no entanto, com os impactos da crise econômica mundial e da queda do preço do petróleo, a participação veio caindo até representar apenas $4 \%$ das receitas totais em 2016, ano de auge da crise fiscal. ${ }^{13}$

Já em 2017, os 92 municípios do RJ registraram aumento de 53\% nas compensações financeiras recebidas em comparação com 2016, totalizando $R \$ 3,9$ bilhões (a maior variação sendo decorrente das participações especiais). E em 2018, como será analisado adiante, as compensações recebidas pelos municípios somaram $\mathrm{R} \$$ 7,4 bilhões, equivalentes a $12 \%$ dos orçamentos. 0 Gráfico 1 evidencia a volatilidade associada às rendas petrolíferas, e é sugestivo dos riscos associados à dependência que os orçamentos possuem desses recursos.

\footnotetext{
12 Ver e Nazareth, Araújo e Oliveira (2018) para análise dos impactos.

13 Santos e Nazareth (2018).
} 
A Figura 2 compara o aumento da produção de petróleo e gás natural no Brasil, no RJ e nos estados de ES e SP, desde 2000, evidenciando que a produção no RJ dobrou entre aquele ano e 2018; apesar do desempenho, a produção nacional aumentou mais no mesmo período, $25 \%$ acima do crescimento da produção do RJ, especialmente nos estados indicados, ES e SP.

Figura2. Produção de Petróleo e Gás Natural - Brasil X principais estados produtores - 2000/2018 Fonte: ANP. Anuário Estatístico 2019. Disponível em: http://www.anp.gov.br/publicacoes/anuario-estatistico/5237-anuario-estatistico-2019

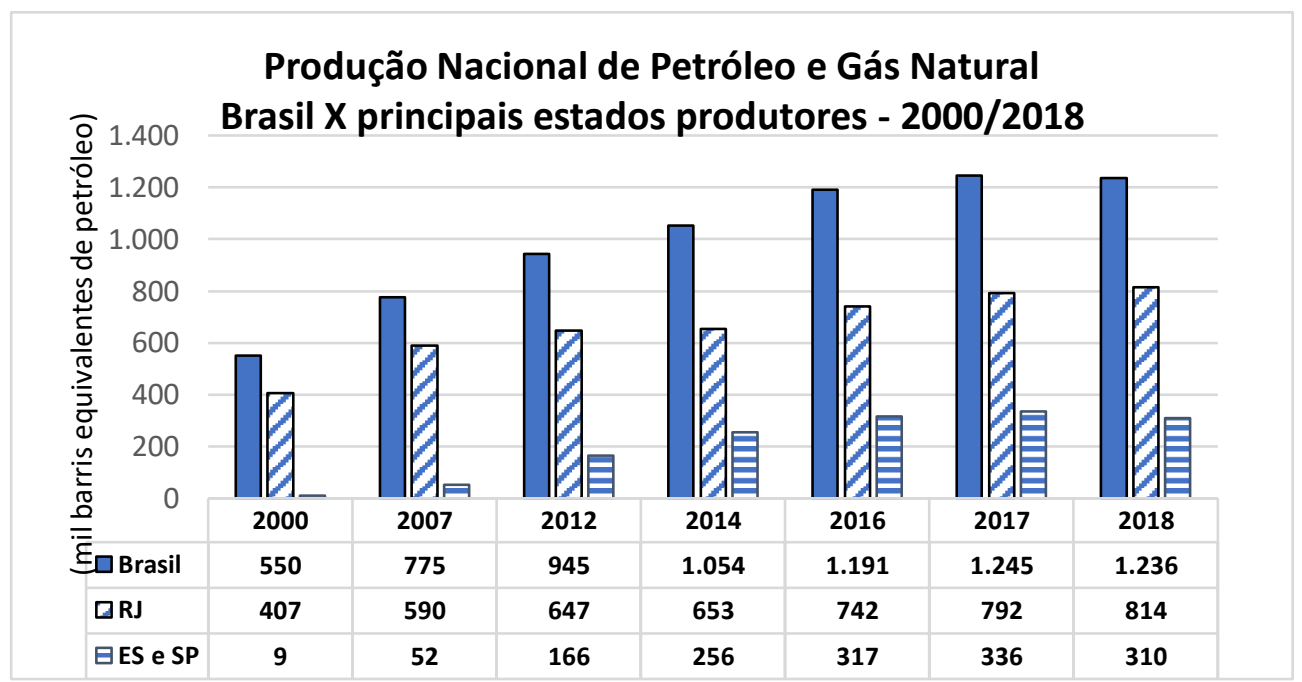

Em boa medida, como indica o Gráfico 2, o aumento menos que proporcional da produção fluminense deve-se ao fato apontado na introdução deste capítulo: a busca de maior rentabilidade dos investimentos, no período recente, que implicou o redirecionamento de recursos para as promissoras áreas do pré-sal especialmente na Bacia de Santos (localizada na plataforma continental confrontante com o Rio de Janeiro e São Paulo), que apresentam maior produtividade e menores custos de produção vis-a-vis a produção nos campos maduros, em declínio, da Bacia de Campos (localizada na plataforma continental confrontante com o Rio de Janeiro e Espírito Santo). ${ }^{14}$

Nesse cenário, a produção do Estado do Rio de Janeiro, embora crescente, vem perdendo participação, tendo passado de 74\% do total nacional em 2000, para 66\% em 2018. Esta perda vem sendo compensada pelo Estado do Espírito Santo - cuja produção passou de 1\% para 12\% - e principalmente por São Paulo, que cresce a uma velocidade maior, passando de $3 \%$ em 2000 para $13 \%$ do total nacional em $2018 .{ }^{15}$

\footnotetext{
14 Nazareth, Araújo e Oliveira (2018).

${ }^{15}$ ANP. Disponível em http://www.anp.gov.br/wwwanp/dados-estatisticos. Acesso em 01/07/2019.
} 
Os impactos dessa mudança do interesse exploratório sobre a produção são muito relevantes para as economias e as finanças públicas regionais e vem alterando o cenário regional, no qual, por muitos anos, os municípios da região Norte Fluminense, principalmente Macaé e Campos, concentraram parcela expressiva de receitas das compensações financeiras pagas pela indústria de petróleo e gás natural.

No período recente, no entanto, já se registra mudança significativa dos pagamentos das participações governamentais dentro do próprio Estado do Rio, com redução dos valores recebidos pelos municípios dessa região, tradicionalmente beneficiária, onde estão os campos maduros da Bacia de Campos, em direção aos municípios mais ao sul do Estado.

De fato, os impactos desse deslocamento em termos de ganhos de receitas já são sentidos no Rio de Janeiro e em Niterói, mas principalmente em Maricá, atualmente o mais beneficiado no país pelas rendas petrolíferas pagas pela exploração do supercampo de Lula, localizado no pré-sal, e hoje o maior produtor nacional.

Ou seja, embora os municípios da região norte tenham perdido (e estejam perdendo) participação no total distribuído, os municípios mais ao sul, incluindo Maricá, Niterói, a capital e Paraty estão sendo beneficiados pela exploração do pré-sal. O conjunto dos municípios fluminenses continua assim garantindo o recebimento de expressivas rendas petrolíferas.

Antes de tratar da importância dessas receitas para os municípios fluminenses, contudo, vale apresentar brevemente como são distribuídas as rendas petrolíferas. ${ }^{16}$

Conforme a Constituição federal (CF/88), a exploração do petróleo é monopólio da União (art. 177), sendo assegurada aos Estados, ao Distrito Federal e aos Municípios, bem como a órgãos da administração direta da União, participação no resultado da exploração de petróleo ou gás natural, de recursos hídricos para fins de geração de energia elétrica e de outros recursos minerais no respectivo território, plataforma continental, mar territorial ou zona econômica exclusiva, ou compensação financeira por essa exploração (art. 20, §1의.

Regulamentando o dispositivo constitucional, a lei federal no 7.990/89 instituiu e definiu os percentuais da distribuição da compensação financeira; estipulou que os pagamentos de royalties seriam mensais (alterando legislação anterior); e estabeleceu vedações à aplicação dos recursos, tendo o decreto no 01/91 regulamentado o seu pagamento e alterado a forma de aplicação, dispondo que estados e municípios

\footnotetext{
16 Ver Nazareth, Araújo e Salles (2011) e Nazareth, Araújo e Oliveira (2018), para análises mais detalhadas das mudanças no marco legal desde as descobertas do pré-sal.
} 
deveriam aplicá-los exclusivamente em energia, pavimentação de rodovias, abastecimento e tratamento de água, irrigação, proteção ao meio ambiente e em saneamento básico. ${ }^{17}$

A lei federal no 7.990/89 manteve a forma de partilha entre os municípios instituída anteriormente, mas acrescentou nova regra: que os estados passassem a transferir a seus municípios $25 \%$ das parcelas das compensações financeiras por eles recebidas, seguindo os mesmos critérios e prazos de distribuição do ICMS. $^{18}$

Além disso, os municípios com instalações marítimas e terrestres de embarque ou desembarque de óleo bruto ou gás natural foram privilegiados pela nova lei, que lhes destinou um adicional de 0,5\% (subtraído, no caso da lavra em terra, da parcela dos estados produtores, que caiu de $4 \%$ para 3,5\%, e, no caso da lavra em plataforma continental, da parcela do Fundo Especial do Petróleo).

Estas modificações evidenciaram uma tendência de municipalização na distribuição dos recursos, com favorecimento dos municípios diretamente afetados pela produção e também de todos os municípios do estado produtor, mediante a transferência dos $25 \%$ de sua parcela - que não se prende ao caráter indenizatório da compensação financeira pela exploração de petróleo e gás.

A lei também inovou no que diz respeito à aplicação dos recursos recebidos pelos entes, vedando que fossem usados para o pagamento do quadro permanente de pessoal e no pagamento de dívidas (art. 8으).

Com relação às vedações, cabe ressaltar (adiantando no tempo a análise que é desenvolvida mais adiante) que a legislação aprovada posteriormente foi afrouxando esta previsão. Com efeito, a lei federal no 10.195/01, que tratou das medidas relativas à reestruturação e ajuste fiscal dos Estados, excetuou o pagamento das dívidas contraídas com a União e suas entidades e permitiu que os recursos de royalties fossem utilizados para capitalização de fundos de previdência. ${ }^{19}$

Mais tarde, a lei federal no 12.858/13 excluiu dessa vedação “o custeio de despesas com manutenção e desenvolvimento do ensino, especialmente na educação básica pública em tempo integral, inclusive as relativas a pagamento de salários e outras verbas de natureza remuneratória a profissionais do magistério em efetivo exercício na rede pública". Ou seja, gastos com remuneração de professores passam a ser - os únicos - gastos com pessoal permitidos, embora o disposto alterado (art.8o da lei 7.990/89) refira-se apenas à parcela de royalties até $5 \%$.

\footnotetext{
17 O Decreto no 01/91 aprofundou a metodologia de cálculo dos pagamentos para cada zona, dentre outras especificações.

18 Os critérios de distribuição do ICMS aos municípios estão definidos no art. 158, inciso IV e respectivo parágrafo único da CF/88.

19 Lei federal no $7.990 / 89$, §§ 1 으 e 2 으 do artigo 8ㅇ.
} 
Retomando a análise da evolução do marco legal, em 1995, a Emenda Constitucional no 09 flexibilizou o monopólio do petróleo exercido pela Petrobras desde 1953, permitindo à União contratar com empresas nacionais e estrangeiras a exploração das atividades ligadas ao petróleo e gás previstas no art. 177 da CF/88, mediante concessão ou autorização.

Na concessão, o concessionário exerce por sua conta e risco as atividades de exploração, adquire a propriedade dos hidrocarbonetos eventualmente produzidos e paga, ao poder concedente, participações governamentais.

O regime de concessão foi regulamentado pela lei federal no 9.478/97, conhecida como Lei do Petróleo, que, entre vários dispositivos relevantes, manteve o percentual de royalties em $5 \%$, previstos na lei no 7.990/89 e os critérios anteriormente estipulados, além de introduzir nova parcela de royalties (excedentes a 5\%) e três novas participações governamentais: bônus de assinatura, pagamento pela ocupação ou retenção de área e participação especial, destacando-se como mais relevantes, especialmente para a análise desenvolvida neste trabalho, os royalties e a participação especial. ${ }^{20}$

De forma resumida, o bônus de assinatura consiste no pagamento ofertado na proposta para obtenção da concessão, cujo valor mínimo é estabelecido no edital e pago no ato da assinatura do contrato; o pagamento pela ocupação ou retenção de área é feito anualmente e fixado por quilômetro quadrado ou fração da superfície do bloco, na forma regulamentada por decreto do Presidente da República, e a participação especial é uma compensação financeira extraordinária devida nos casos de grande volume de produção, ou de grande rentabilidade, pagas trimestralmente e calculadas num percentual progressivo que varia entre $0 \%$ e $40 \%$ sobre a receita líquida da produção. ${ }^{21}$

As regras de rateio da parcela de royalties até $5 \%$ não foram alteradas, mas com relação às novas participações - royalties excedentes a 5\% e participações especiais - houve um direcionamento primordial dos recursos aos estados e municípios produtores confrontantes e afetados pelas operações de embarque e desembarque, e para a União (Ministérios da Marinha, Minas e Energia, Meio Ambiente e Ciência e Tecnologia) visando promover atividades diretamente ligadas à economia do petróleo, seja de pesquisa e desenvolvimento, seja de fiscalização e proteção, aprofundando o entendimento de que os recursos gerados no setor de petróleo devem ser destinados aos entes diretamente impactados por esta atividade e para as instâncias reguladoras e fiscalizadoras.

A seguir, os critérios de distribuição vigentes sob o regime de concessão:

20 O decreto no 2.705/98 definiu os critérios para cálculo e cobrança das participações governamentais.

${ }^{21}$ Sobre a receita bruta da produção, são deduzidos royalties, investimentos na exploração, custos operacionais, depreciação e tributos previstos na legislação (art. 50, § 10 da lei no 9.478/97). 


\section{Exploração sob o regime de Concessão}

1. Royalties: alíquota varia entre $5 \%$ a $10 \%$ sobre a receita bruta da produção.

i. Parcela até $5 \%$ (arts. 48 da LF no 9.478/97 e 70 da LF no 7.990/89):

- $30 \%$ Estados confrontantes com poços

- 30\% Municípios confrontantes com poços e respectivas áreas geoeconômicas

- $20 \%$ Comando da Marinha

- $10 \%$ Fundo Especial (estados, DF e municípios)

- 10\% Municípios com instalações de embarque e desembarque de petróleo e gás natural

ii. Parcela excedente a 5\% (arts. 47 e 49 da LF no 9.478/97):

- 25\% Ministério da Ciência e Tecnologia

- $22,5 \%$ Estados confrontantes com campos

- $22,5 \%$ Municípios confrontantes com campos

- $15 \%$ Comando da Marinha

- $7,5 \%$ Fundo Especial (estados, DF e municípios)

- 7,5\% Municípios afetados por operações nas instalações de embarque e desembarque de petróleo e gás natural

2. Participação Especial: alíquota varia entre $0 \%$ e $40 \%$ sobre a receita líquida da produção (art. 50 da LF ํo 9.478/97 e Decreto no 2.705/98):

- $40 \%$ Ministério de Minas e Energia

- $\quad 10 \%$ Ministério do Meio Ambiente, dos Recursos Hídricos e da Amazônia Legal

- $10 \%$ Municípios confrontantes com campos

- $40 \%$ Estados confrontantes com campos 
Voltando à questão da aplicação das receitas, cabe destacar que a lei n.o 9.478/97 não estabeleceu restrições aos estados e municípios, tampouco vinculou sua utilização a determinado tipo de gasto, restando na legislação apenas as restrições anteriormente previstas na lei no 7.990/1989 relativas aos royalties até 5\%.

Esta lacuna, portanto, pode levar à interpretação de que as vedações só valem para os royalties até 5\%, enquanto as outras participações governamentais poderiam ser utilizadas pelos gestores estaduais e municipais de forma discricionária, isto é, sem vedação. ${ }^{22}$ No caso da União, a utilização dos recursos está bem definida na legislação.

Mudanças no marco legal desde a descoberta do pré-sal

As descobertas no pré-sal, anunciadas em $2007^{23}$, e as expectativas de grande aumento da produção nacional em decorrência de sua exploração levaram o governo federal a propor um novo marco regulatório para o setor do petróleo, tendo sido aprovadas em 2010 três leis: a 12.276/2010 (cessão onerosa), a $12.304 / 2010^{24}$ (criação da empresa Pré-Sal Petróleo - PPSA) e a 12.351/2010 ${ }^{25}$ (partilha de produção e Fundo Social), com o objetivo declarado de aumentar o controle e a participação da União nos futuros empreendimentos bem como a parcela de receitas a ser apropriada pelo governo federal.

Foram estabelecidos como receitas governamentais no regime de partilha os royalties e o bônus de assinatura. $^{26}$ O percentual de royalties foi aumentado para $15 \%$ da produção; o novo modelo, em compensação, não prevê o pagamento de participações especiais, extinguindo importante fonte de compensação aos entes produtores.

Depois de três anos de discussões e debates, foi aprovada a Lei no 12.734/13, que modificou as leis do Petróleo e da Partilha), prevendo as novas regras de distribuição dos royalties no modelo de partilha e alterando as regras de distribuição dos royalties e das participações especiais no modelo de concessão.

Com as alterações promovidas, a lei no 12.351/2010 passou a prever que os royalties com alíquota de 15\% no regime de partilha de produção sejam distribuídos da seguinte forma:

Royalties: alíquota de $15 \%$ sobre a receita bruta da produção

\footnotetext{
22 Este tem sido o entendimento adotado até o momento pelo Tribunal de Contas do Estado do RJ (TCE-RJ), ao exercer a fiscalização sobre a aplicação dos recursos, na análise de processos de contas de governos municipais.

23 Nazareth, Araújo e Oliveira, 2018.

24 Alterada posteriormente pela lei federal no 13.679/18.

25 Alterada posteriormente pelas leis federais $n$ ㅇ $12.734 / 12$ e 13.365/16.

${ }^{26}$ Quando o bloco se localizar em terra, haverá ainda o pagamento de participação equivalente a até $1 \%$ do valor da produção de petróleo ou gás natural aos proprietários da terra onde se localiza o bloco, calculado pela ANP (Lei no 12.351/2010, art. 43).
} 
1. Quando a produção ocorrer em terra, rios, lagos, ilhas lacustres ou fluviais:

- $20 \%$ para Estados produtores;

- $10 \%$ para Municípios produtores;

- $5 \%$ para Municípios afetados por operações de embarque e desembarque de petróleo, gás natural e outro hidrocarboneto fluido;

- $25 \%$ para constituição de fundo especial, a ser distribuído entre Estados e o Distrito Federal (segundo as mesmas regras do FPE);

- $25 \%$ para constituição de fundo especial, a ser distribuído entre os Municípios (segundo as mesmas regras do FPM);

- $15 \%$ para a União, a ser destinado ao Fundo Social, deduzidas as parcelas destinadas aos órgãos da União.

2. Quando a produção ocorrer na plataforma continental, no mar territorial ou na zona econômica exclusiva:

- $22 \%$ para Estados confrontantes;

- $5 \%$ para Municípios confrontantes;

- 2\% para Municípios afetados por operações de embarque e desembarque de petróleo, gás natural e outro hidrocarboneto fluido;

- $24,5 \%$ para constituição de fundo especial, a ser distribuído entre Estados e o Distrito Federal (segundo as mesmas regras do FPE);

- 24,5\% para constituição de fundo especial, a ser distribuído entre os Municípios (segundo as mesmas regras do FPM);

- $22 \%$ para a União, a ser destinado ao Fundo Social, deduzidas as parcelas destinadas aos órgãos da União.

No caso dos critérios para exploração de petróleo na plataforma continental, em que se enquadram o estado do Rio de Janeiro e os municípios fluminenses, observa-se uma inversão total na destinação dos recursos, privilegiando os entes não produtores. 
De fato, no modelo de partilha, os estados confrontantes só recebem $22 \%$ dos royalties, enquanto na concessão recebiam $30 \%$ dos royalties até $5 \%$ e $22,5 \%$ dos royalties excedentes, além de $40 \%$ das participações especiais.

Os maiores perdedores, contudo, são os municípios confrontantes que no modelo de partilha só recebem $5 \%$ dos royalties, contra $30 \%$ dos royalties até $5 \%, 22,5 \%$ dos royalties excedentes e $10 \%$ das participações especiais, no regime de concessão com as regras anteriores.

Municípios afetados por operações ou com instalações de embarque e desembarque também perdem: passam a receber apenas $2 \%$ dos royalties, enquanto na concessão recebiam $10 \%$ dos royalties até $5 \%$ e $7,5 \%$ dos royalties excedentes.

O fundo especial destinado a todos os estados e municípios ganha: passa a receber $49 \%$ do total dos royalties, desdobrado em dois fundos um para os estados e outro para os municípios (na concessão, o fundo só recebia $10 \%$ dos royalties até $5 \%$ e $7,5 \%$ dos royalties excedentes).

A União recebe $22 \%$ do total na partilha, enquanto no modelo de concessão recebe $20 \%$ dos royalties até $5 \%, 40 \%$ dos royalties excedentes e $50 \%$ das participações especiais.

Além de definir a distribuição para o regime de partilha, a lei no 12.734/2012 também alterou as regras de distribuição para o regime de concessão para exploração em terra e no mar. Para a exploração no mar (plataforma continental) - caso do RJ -, assim como no regime de partilha, as novas regras aplicáveis às concessões também promovem uma inversão total na destinação dos recursos.

Os estados confrontantes passam a receber, respectivamente, $20 \%$ dos royalties até $5 \%, 20 \%$ dos royalties excedentes e $34 \%$ das participações especiais (reduzido anualmente até chegar a $20 \%$ a partir de 2018) pelas novas regras.

Os maiores perdedores, assim como no modelo de partilha, são os municípios confrontantes e afetados e aqueles com instalações de embarque e desembarque. Pelas novas regras, passam a receber $17 \%$ dos royalties até $5 \%$ e dos royalties excedentes, percentuais a serem reduzidos anualmente até o mínimo de $4 \%$ a partir de 2019, e 5\% das participações especiais, também a ser reduzido a 4\% em 2019. Já os municípios afetados pelas operações de embarque e desembarque passam a receber $3 \%$ tanto dos royalties até $5 \%$ quanto dos royalties excedentes.

Por sua vez, o fundo especial destinado a todos os estados e municípios será substituído por um fundo especial destinado aos estados e ao Distrito Federal e outro para todos os municípios, que receberão $20 \%$ dos royalties até $5 \%$ e excedentes cada um (percentual progressivamente majorado até atingir o máximo de $27 \%$ a partir de 2019), além de 9,5\% das participações especiais cada um (percentual progressivamente majorado 
até atingir o máximo de $15 \%$ a partir de 2019), com recursos distribuídos de acordo com os mesmos critérios do FPE e do FPM respectivamente.

A União, que recebia 20\% dos royalties até 5\% (Ministério da Marinha), 40\% dos royalties excedentes (Ministério da Ciência e Tecnologia e Ministério da Marinha) e 50\% das participações especiais (Ministério das Minas e Energia e Ministério do Meio Ambiente) no modelo de concessão anterior, passa a receber, respectivamente, 20\%, 20\% e 42\%, sendo todas essas parcelas destinadas ao Fundo Social.

A Lei no 12.351/2010 e a Lei no 9.478/1997 alterada preveem que os estados e municípios produtores e confrontantes que receberem royalties e participações especiais não receberão recursos do fundo especial, que deverão ser destinados exclusivamente aos entes não enquadrados naquelas categorias. Os entes confrontantes, não obstante, poderão optar entre receber os royalties e participações especiais que lhes são devidos em vista desse enquadramento ou receber os recursos do fundo especial após conhecidos os valores a serem distribuídos.

As duas leis também estabelecem que a soma dos valores referentes aos royalties e participações especiais devidas aos municípios produtores, confrontantes e afetados por operações de embarque e desembarque nos contratos de partilha e concessão ficarão limitados ao maior dos seguintes valores: (i) os valores que o município recebeu a título de royalties e participações especiais em 2011; (ii) duas vezes o valor per capita distribuído pelo FPM, calculado em nível nacional, multiplicado pela população do município, sendo que a parcela dos royalties e participações especiais que exceder esse limite será transferida para o fundo especial a ser distribuído entre todos os municípios.

\section{Destinação dos recursos}

Quanto à destinação dos recursos das participações governamentais no novo marco regulatório do petróleo, além da criação do Fundo Social no âmbito da União, a lei no 12.351/10 alterada pela lei no $12.734 / 12$ previu que os recursos dos fundos especiais dos estados e municípios (tanto no modelo de partilha quanto no de concessão) deverão ser destinados às áreas de educação, infraestrutura social e econômica, saúde, segurança, programas de erradicação da miséria e da pobreza, cultura, esporte, pesquisa, ciência e tecnologia, defesa civil e meio ambiente, em programas voltados para a mitigação e adaptação às mudanças climáticas e para o tratamento e reinserção social dos dependentes químicos. Os entes devem encaminhar anexo contendo a previsão para aplicação desses recursos junto aos respectivos planos plurianuais, leis de diretrizes orçamentárias e do orçamento anual. 
Posteriormente, foi aprovada a lei federal no 12.858/2013 também destinando às áreas de educação e saúde recursos das participações governamentais. A finalidade foi dar cumprimento à meta constitucional de aplicação de recursos públicos em educação como proporção do produto interno bruto ${ }^{27}$ e assegurar recursos para o financiamento de políticas sociais e econômicas que visem à garantia da saúde como direito de todos e dever do Estado, conforme previsão do artigo 196 da Constituição Federal.

Esses recursos deverão ser aplicados, por todos os entes federativos, no montante de $75 \%$ na área de educação e de $25 \%$ na área de saúde e em acréscimo aos mínimos obrigatórios previstos na Constituição Federal $^{28}$.

Os royalties e participações especiais destinados à União provenientes de campos que operam sob o regime de concessão localizados no pré-sal, cuja declaração de comercialidade tenha ocorrido antes de 3 de dezembro de 2012, serão integralmente destinados ao Fundo Social, conforme determinado pela mesma lei $12.858 / 2013$.

Não resta dúvida, portanto, que a Lei no 12.858/2013 veio preencher a lacuna que havia na legislação quanto à destinação das receitas do petróleo, uma vez que determina a aplicação em educação (75\%) e saúde (25\%) de todas as receitas de royalties e participações especiais recebidas pela administração direta da União e demais entes federativos advindas dos contratos de exploração de petróleo e gás celebrados a partir de 3 de dezembro de 2012 quando a lavra ocorrer na plataforma continental, no mar territorial ou na zona econômica exclusiva sob qualquer regime (concessão, partilha de produção ou cessão onerosa).

\section{A importância das rendas petrolíferas para os orçamentos municipais}

Como observado anteriormente, os novos critérios de rateio contidos na legislação de 2012 tiveram seus efeitos suspensos pelo STF em 2013, em função de ações diretas de inconstitucionalidade ajuizadas por alguns estados produtores, insatisfeitos com o novo marco regulatório.

A decisão definitiva só deverá ser dada após julgamento pelo plenário do Supremo Tribunal, previsto para ocorrer no mês de novembro de 2019, já havendo movimentação dos estados produtores solicitando o adiamento para 2020. Como noticiado na imprensa, o Governo do Estado do Rio de Janeiro protocolou no STF, com outros cinco estados, pedido de suspensão por seis meses da tramitação da Ação Direta de

\footnotetext{
27 Meta prevista no inciso VI do caput do artigo 214 da CF/88, que prevê o estabelecimento do Plano Nacional de Educação, de duração decenal (redação dada pela Emenda Constitucional no 59/2009).

${ }^{28}$ Ou seja, na educação, 25\%, no mínimo, da receita de impostos e transferências na manutenção e no desenvolvimento do ensino (CF/1988, art. 212), e na saúde, 15\% da receita corrente líquida da União (CF/1988, art. 198) e 15\% da arrecadação de impostos e transferências de estados e municípios, conforme Lei Complementar no 141/2012, que regulamentou o §3ㅇdo artigo 198 da CF/88.
} 
Inconstitucionalidade que questiona a redistribuição dos recursos pelos novos critérios, com vistas à proposição de uma audiência de conciliação entre os estados e o Distrito Federal. ${ }^{29}$

Os elevados valores gerados pelas atividades de exploração e produção do petróleo e gás natural tendem a variar muito de ano a ano, não apenas em função de características intrínsecas à exploração desses recursos naturais, não renováveis e de importância geopolítica fundamental para a riqueza dos países, como pela marcada volatilidade dos preços, determinados no mercado internacional, e influenciados pela taxa de câmbio real/dólar.

Além da incerteza quanto aos montantes a serem pagos em cada período pelas razões mencionadas, os valores distribuídos aos entes federativos também tendem a variar muito entre os beneficiados, em virtude dos critérios de rateio, fazendo com que variem muito entre regiões, e mesmo intra regiões, entre municípios vizinhos. ${ }^{30}$

Os impactos das rendas nos territórios são muito significativos, acentuando desigualdades e modificando sensivelmente as receitas e despesas dos orçamentos públicos, interferindo na gestão municipal e na promoção do desenvolvimento.

Além da possibilidade concreta da mudança das regras de distribuição, as características próprias das rendas petrolíferas, acima mencionadas, resultam em incertezas adicionais e impõem que as administrações estejam preparadas para lidar com perdas acentuadas e repentinas de recursos, e com os efeitos negativos que podem advir sobre as políticas públicas - especialmente aquelas relacionadas à gestão urbana e às áreas sociais, como a educação e a saúde, que são de responsabilidade dos municípios e que afetam diretamente a vida da população.

Com o intuito de mostrar a grandeza dos valores envolvidos e a variação a que estão sujeitos, a Tabela 1 apresenta os royalties e as participações especiais decorrentes da exploração de petróleo e gás natural no país, distribuídas pela ANP nos anos de 2007 (antes da eclosão da crise econômica mundial, em 2008), em 2014, 2016 e 2018, por beneficiário, destacando em separado os entes do RJ.

Tabela 1. Royalties e Participações Especiais - 2007, 2014, 2016 e 2018 (em R\$ milhões correntes). Fonte: ANP.

\begin{tabular}{|c|c|c|c|c|c|c|c|c|}
\hline Beneficiário & $\begin{array}{c}\text { Royalties } \\
\text { e PE } \\
2007\end{array}$ & $\begin{array}{l}\% \text { no } \\
\text { total }\end{array}$ & $\begin{array}{c}\text { Royalties } \\
\text { e PE } \\
2014\end{array}$ & $\begin{array}{l}\% \text { no } \\
\text { total }\end{array}$ & $\begin{array}{c}\text { Royalties } \\
\text { e PE } \\
2016\end{array}$ & $\begin{array}{l}\% \text { no } \\
\text { total }\end{array}$ & $\begin{array}{c}\text { Royalties } \\
\text { e PE } \\
2018\end{array}$ & $\begin{array}{l}\% \text { no } \\
\text { total }\end{array}$ \\
\hline União & 5.662 & $39 \%$ & 13.633 & $39 \%$ & 6.270 & $35 \%$ & 21.274 & $40 \%$ \\
\hline
\end{tabular}

\footnotetext{
29 Disponível em: https://bit.ly/2JAQG3k.

${ }^{30}$ A lei do petróleo introduziu, dessa forma, elemento diferenciador entre os municípios da região Norte Fluminense confrontantes com os poços produtores e beneficiados pelas rendas, considerados, por essa razão, "petro-rentistas" (Serra, Terra e Pontes, 2006 apud Piquet, 2017). Ver também Da Cruz e Terra (2015) para a discussão dos impactos na região.
} 


\begin{tabular}{lllllllll}
\hline Estado do RJ & $\mathbf{4 . 3 6 2}$ & $\mathbf{3 0 \%}$ & $\mathbf{8 . 7 0 6}$ & $\mathbf{2 5 \%}$ & $\mathbf{3 . 4 9 3}$ & $\mathbf{2 0 \%}$ & $\mathbf{1 3 . 3 0 9}$ & $\mathbf{2 0 \%}$ \\
Municípios do RJ & $\mathbf{2 . 4 3 5}$ & $\mathbf{1 7 \%}$ & $\mathbf{4 . 7 8 2}$ & $\mathbf{1 4 \%}$ & $\mathbf{2 . 5 3 7}$ & $\mathbf{1 4 \%}$ & $\mathbf{6 . 7 2 9}$ & $\mathbf{1 4 \%}$ \\
Estados (exc.RJ) & 800 & $5 \%$ & 3481 & $10 \%$ & 2.265 & $13 \%$ & 5.114 & $13 \%$ \\
Municípios (exc. RJ) & 824 & $6 \%$ & 3202 & $9 \%$ & 2.160 & $12 \%$ & 4.230 & $12 \%$ \\
Fundo Especial & 577 & $4 \%$ & 1481 & $4 \%$ & 962 & $5 \%$ & 1.944 & $5 \%$ \\
Depósito Judicial & 8 & $0 \%$ & 39 & $0 \%$ & 21 & $0 \%$ & 83 & $0 \%$ \\
Educação e Saúde & & $0 \%$ & 34 & $0 \%$ & 42 & $0 \%$ & 322 & $0 \%$ \\
Total & 14.668 & $100 \%$ & 35.359 & $100 \%$ & 17.750 & $100 \%$ & 53.004 & $100 \%$ \\
\hline
\end{tabular}

A Tabela 1 evidencia como os valores variam ao longo do tempo, pelos fatores mencionados anteriormente - no caso dos royalties, volume de produção do campo (percentual entre $5 \%$ e $10 \%$ incidente sobre a receita bruta), preço do petróleo no mercado internacional (referência) e taxa de câmbio dólar/real; quanto às participações especiais (percentual entre zero e $40 \%$ da receita líquida dos campos com elevado volume de produção e grande produtividade), além dos demais, também incidem fatores que afetam os custos de produção (a serem deduzidos da receita bruta).

É possível constatar o expressivo aumento até 2014, ano em que se registra o valor mais elevado dos pagamentos de participações governamentais. A partir de então, o Brasil sofreu forte impacto da redução do volume demandado e da queda dos preços das commodities, com destaque para o petróleo, em função da desaceleração do crescimento nas economias dos países desenvolvidos e em especial, da economia chinesa.

Entre outros aspectos, a queda do preço do barril de petróleo no mercado internacional (de mais de U\$150, em 2008, para menos de U\$30, em janeiro de 2016) contribuiu decisivamente para a redução à metade das rendas petrolíferas pagas no país pelas empresas concessionárias: de mais de $\mathrm{R} \$ 35$ bilhões em 2014 para menos de R\$ 18 bilhões em 2016 (Tabela 1).

A piora dos indicadores macroeconômicos e fiscais brasileiros em função da crise mundial envolveu a queda do PIB, aumento do desemprego e endividamento público nas esferas federal e estadual e a conversão de superávits em déficits primários das contas públicas em todos os níveis. As receitas públicas de estados e municípios foram impactadas pela crise econômica nacional de muitas formas, com queda nas transferências federais e na arrecadação própria, além das limitações de outras fontes de financiamento, como as operações de crédito. ${ }^{31}$

No Estado do RJ, as rendas do petróleo recebidas também sofreram acentuada queda: o valor das participações recebido pelo governo estadual em 2016 caiu 60\% em relação ao recebido em $2014,{ }^{32}$ enquanto as rendas recebidas pelos municípios do RJ caíram quase 50\% no mesmo período (em termos nominais).

\footnotetext{
${ }^{31}$ Nazareth (2017).

32 Destaque-se que o valor de 2014 foi o maior da década.
} 
Em 2018, com a recuperação dos preços e o aumento da produção no pré-sal, as rendas petrolíferas distribuídas somaram $\mathrm{R} \$ 53$ bilhões (Tabela 1), aumento de $200 \%$ com relação a 2016, especialmente em participações especiais. ${ }^{33}$

O elevado nível de descentralização das receitas possibilitou que os governos subnacionais recebessem expressiva parcela dos royalties e participações especiais pagos pelas empresas concessionárias: os estados ficaram com 33\% (R\$18,4 bilhões), e os municípios com 26\% (R\$10,9 bilhões), do total.

Esses valores, como já mencionado, não são distribuídos de forma igual pelos entes federativos, em razão dos critérios de distribuição, que privilegiam a proximidade geográfica com os campos produtores hoje, de forma preponderante, localizados na plataforma continental brasileira, com a exploração em poços do pós-sal e, de maneira crescente, em águas profundas no pré-sal.

Por isso, em 2018, segundo a ANP, somente 11 dos 27 estados receberam royalties e 6 fizeram jus a participações especiais. Quanto aos governos locais, seguindo os critérios de distribuição, 1.009 entes municipais (ou seja, 18\% dos 5.570 municípios), de 18 estados brasileiros, receberam $R \$ 8$ bilhões de royalties, enquanto 48 municípios, de 5 estados, receberam R\$2,9 bilhões em participações especiais. A Tabela 2 resume os valores de R\&PE recebidos em 2018 pelos municípios beneficiários das participações governamentais, segundo os respectivos Estados.

Tabela 2. Distribuição de Royalties e Participação Especial (R\&PE) aos Municípios Beneficiários, segundo os respectivos Estados 2018 (em mil reais correntes) Fonte: ANP/SPG, conforme a Lei $n^{\circ}$ 9.478/1997 e o Decreto ${ }^{\circ} 2.705 / 1998$.

\begin{tabular}{|c|c|c|c|c|c|c|}
\hline $\begin{array}{l}\text { Estados com } \\
\text { Municípios } \\
\text { Beneficiários }\end{array}$ & $\begin{array}{l}\text { Royalties } \\
\text { recebidos em } \\
2018\end{array}$ & $\begin{array}{c}\text { no de } \\
\text { Municípios } \\
\text { beneficiários } \\
\text { de Royalties }\end{array}$ & $\begin{array}{c}\text { PE recebida } \\
\text { em } 2018\end{array}$ & $\begin{array}{c}\text { no de } \\
\text { Municípios } \\
\text { beneficiários } \\
\text { de PE }\end{array}$ & $\begin{array}{l}\text { Royalties \& } \\
\text { PE total } \\
2018\end{array}$ & $\begin{array}{l}\% \text { no } \\
\text { total }\end{array}$ \\
\hline Alagoas & $116.469,0$ & 52 & - & & $116.469,0$ & $1 \%$ \\
\hline Amazonas & $116.854,6$ & 20 & $11.133,0$ & 2 & $127.987,6$ & $1 \%$ \\
\hline Amapá & 279,1 & 3 & & & 279,1 & $0 \%$ \\
\hline Bahia & $368.061,5$ & 269 & $1.746,0$ & 2 & $369.807,5$ & $3 \%$ \\
\hline Ceará & $106.729,5$ & 83 & & & $106.729,5$ & $1 \%$ \\
\hline Espírito Santo & $883.507,0$ & 78 & $270.683,0$ & 3 & $1.154 .190,0$ & $11 \%$ \\
\hline Maranhão & $70.166,9$ & 6 & & & $70.166,9$ & $1 \%$ \\
\hline Minas Gerais & $12.687,7$ & 6 & & & $12.687,7$ & $0 \%$ \\
\hline Pará & $1.581,7$ & 17 & & & $1.581,7$ & $0 \%$ \\
\hline Paraíba & $42.455,8$ & 9 & & & $42.455,8$ & $0 \%$ \\
\hline Pernambuco & $60.695,6$ & 18 & & & $60.695,6$ & $1 \%$ \\
\hline Paraná & $2.630,9$ & 38 & & & $2.630,9$ & $0 \%$ \\
\hline Rio de Janeiro & $4.451 .383,6$ & 87 & $2.277 .949,0$ & 14 & $6.729 .332,6$ & $61 \%$ \\
\hline Rio Grande do Norte & $250.719,1$ & 98 & & & $250.719,1$ & $2 \%$ \\
\hline
\end{tabular}

\footnotetext{
33 Somado o expressivo valor de R\$15 bilhões em bônus de assinatura, decorrente dos contratos assinados com a realização dos leilões naquele ano, o total arrecadado e distribuído em 2018 chegou a R\$68 bilhões. Segundo a ANP/SPL, os bônus foram arrecadados em Rodadas de Licitações de blocos exploratórios e nas 3a e 4a Rodadas de Licitações de Áreas com Acumulações Marginais (http://rodadas.anp.gov.br/pt/). Como proporção do PIB os royalties do petróleo cresceram de 0,68\% para $1 \%$ do PIB entre de 2017 e 2018 , expansão de 0,32 ponto, que representou quase $25 \%$ de toda a expansão da carga tributária no período ( 1,33 ponto do PIB). (Afonso e Castro, 2019)
} 


\begin{tabular}{|c|c|c|c|c|c|c|}
\hline Rio Grande do Sul & $89.088,0$ & 26 & & & $89.088,0$ & $1 \%$ \\
\hline Santa Catarina & $69.644,8$ & 14 & & & $69.644,8$ & $1 \%$ \\
\hline Sergipe & $214.724,3$ & 75 & & & $214.724,3$ & $2 \%$ \\
\hline São Paulo & $1.144 .466,4$ & 110 & $395.198,0$ & 5 & $1.539 .664,4$ & $14 \%$ \\
\hline Municípios & $8.002 .145,5$ & 1.009 & $2.956 .709,0$ & 26 & $10.958 .854,5$ & $100 \%$ \\
\hline
\end{tabular}

http://www.anp.gov.br/arquivos/central-conteudos/anuario-estatistico/2019/anuario-2019-tabela-2.17.xls http://www.anp.gov.br/arquivos/central-conteudos/anuario-estatistico/2019/anuario-2019-tabela-2.18.xls

Como se observa na última coluna da Tabela 2, e já mencionado, os valores pagos variaram muito entre os entes. Os municípios dos estados do RJ (principalmente), SP e ES foram, por ordem de importância, os que mais receberam recursos em 2018, com participações de $61 \%$, $14 \%$ e $11 \%$ respectivamente, do total distribuído.

Os municípios do RJ e SP, que fazem confrontação com os campos das principais bacias produtoras do país - de Campos e de Santos, receberam 75\% dos R\&PE pagos pelas empresas em 2018. Se consideradas as participações governamentais pagas aos governos estaduais, os entes federativos paulistas e fluminenses, em seu conjunto, receberam $81 \%$ de tudo o que foi pago a estados e municípios brasileiros em 2018.

E apesar da perda de importância relativa no cenário nacional, os municípios do RJ receberam $56 \%$ dos royalties e $77 \%$ das participações especiais pagas pela ANP aos municípios brasileiros, percentuais que eram de $64 \%$ e $100 \%$ em $2000 .^{34}$

Com o intuito de avaliar o peso das rendas petrolíferas nos orçamentos dos municípios, a Tabela 3 apresenta o indicador do Grau de Dependência, por estado, comparando os valores agregados de royalties e participações especiais recebidos às receitas totais arrecadadas pelo conjunto dos municípios de cada estado da federação em 2018.

Os dados são do Sistema de Informações sobre Orçamentos Públicos em Saúde (SIOPS/Datasus) do Ministério de Saúde, a base com informações mais completas das receitas municipais de 2018, na data do levantamento realizado (agosto de 2019).

Com relação a esse ponto, cabe destacar as dificuldades relacionadas ao uso dos dados das finanças municipais, não apenas no que diz respeito à divergência dos dados que constam das diferentes bases utilizadas (Siconfi da Secretaria do Tesouro Nacional; Siops do Ministério de Saúde; e o Sigfis, do TCE-RJ, além da Agência Nacional de Petróleo - ANP), como também a ausência de informações ou ainda o registro, pelos municípios, de receitas em classificações equivocadas. Daí resultando divergências de números entre as diferentes fontes de dados, mas que não são relevantes a ponto de comprometer os resultados encontrados na análise.

${ }^{34}$ ANP - http://www.anp.gov.br/royalties-e-outras-participacoes/participacoes-governamentais-consolidadas. 
Tabela 3. Grau de Dependência das receitas municipais com compensação financeira do petróleo e gás natural (R\&PE) - 2018 Municípios segundo os respectivos Estados (em mil reais correntes). Fonte: SIOPS/MS. www.siops. datasus.gov.br.

\begin{tabular}{|c|c|c|c|}
\hline $\begin{array}{l}\text { Municípios } \\
\text { dos Estados }\end{array}$ & $\begin{array}{l}\text { Total R\&PE recebidos } \\
\text { pelos municípios } \\
\text { (1) }\end{array}$ & $\begin{array}{c}\text { Total geral das Receitas } \\
\text { Municipais Líquidas } \\
\text { (2) }\end{array}$ & $\begin{array}{c}\text { Grau de } \\
\text { Dependência } \\
2018(1 / 2) \\
\end{array}$ \\
\hline$A C$ & $8.541,9$ & $1.867 .405,3$ & $0,5 \%$ \\
\hline$A L$ & $156.126,9$ & $9.001 .666,0$ & $1,7 \%$ \\
\hline AM & $183.886,8$ & $9.410 .245,4$ & $2,0 \%$ \\
\hline $\mathrm{AP}$ & $1.808,5$ & $874.385,4$ & $0,2 \%$ \\
\hline $\mathrm{BA}$ & $514.740,2$ & $36.847 .995,0$ & $1,4 \%$ \\
\hline CE & $186.325,9$ & $22.663 .505,2$ & $0,8 \%$ \\
\hline DF & $\mathrm{NI}$ & $\mathrm{NI}$ & $\mathrm{NI}$ \\
\hline ES & $1.229 .334,1$ & $12.264 .608,6$ & $10,0 \%$ \\
\hline GO & $60.754,5$ & $19.418 .757,8$ & $0,3 \%$ \\
\hline MA & $134.413,9$ & $15.809 .461,6$ & $0,9 \%$ \\
\hline MG & $215.817,9$ & $58.350 .124,2$ & $0,4 \%$ \\
\hline MS & $20.434,1$ & $10.768 .303,2$ & $0,2 \%$ \\
\hline MT & $29.188,3$ & $10.871 .175,6$ & $0,3 \%$ \\
\hline PA & $56.436,3$ & $18.619 .803,9$ & $0,3 \%$ \\
\hline PB & $82.125,1$ & $9.760 .652,7$ & $0,8 \%$ \\
\hline $\mathrm{PE}$ & $134.710,5$ & $21.554 .518,8$ & $0,6 \%$ \\
\hline $\mathrm{PI}$ & $40.815,8$ & $9.075 .708,0$ & $0,4 \%$ \\
\hline PR & $107.180,8$ & $36.445 .533,7$ & $0,3 \%$ \\
\hline RJ & $7.367 .817,0$ & $61.608 .209,6$ & $12,0 \%$ \\
\hline RN & $315.659,6$ & $8.613 .509,3$ & $3,7 \%$ \\
\hline RO & $13.866,9$ & $4.581 .230,1$ & $0,3 \%$ \\
\hline $\mathrm{RR}$ & $7.962,3$ & $1.724 .411,6$ & $0,5 \%$ \\
\hline RS & $162.124,8$ & $40.417 .482,4$ & $0,4 \%$ \\
\hline SC & $121.329,0$ & $26.502 .613,2$ & $0,5 \%$ \\
\hline SE & $247.051,1$ & $6.061 .881,0$ & $4,1 \%$ \\
\hline SP & $1.835 .500,9$ & $163.144 .752,4$ & $1,1 \%$ \\
\hline TO & $20.961,0$ & $4.685 .418,4$ & $0,4 \%$ \\
\hline Total Brasil (3) & $13.186 .498,0$ & $620.943 .358,2$ & $2,1 \%$ \\
\hline
\end{tabular}

(1) Inclui Royalties até 5\% e excedentes (1.7.21.22.30.00 e 1.7.21.22.40.00); Participações Especiais (1.7.21.22.50.00); Fundo Especial do Petróleo - FEP (1.7.21.22.70.00) e a cota-Parte de $25 \%$ dos Royalties até $5 \%$ recebidos pelos Estados (1.7.22.22.30.00).

(2) Receitas realizadas brutas - deduções das receitas - dedução para formação do Fundeb.

(3) Dados referentes a 5.569 municípios.

A Tabela 3 evidencia o peso desigual das rendas do petróleo e gás para os orçamentos municipais, variando de um mínimo de 0,2\%, nos estados do AP, MT e MS, a um máximo de $12 \%$ no RJ e $10 \%$ no ES. Apesar da elevada arrecadação de rendas do petróleo e gás, os municípios de SP, terceiro maior produtor, apresentam reduzida dependência, apenas $1,1 \%$, o que se deve à expressiva participação de receitas de outras fontes nos seus orçamentos.

Tendo em vista a importância para os entes do RJ, a Tabela 4 detalha o grau de dependência dos municípios fluminenses e as rendas petrolíferas per capita em 2019, agregando-os de acordo com o enquadramento em zonas de produção divulgado pela ANP, e indicando o número de municípios em cada zona. 
Tabela 4. Grau de Dependência e rendas petrolíferas (R\&PE) per capita, Municípios do RJ - 2018 (em mil reais correntes). Fonte: SIOPS/MS. www.siops.datasus.gov.br. ANP e IBGE (população).

\begin{tabular}{lccrrrr}
\hline $\begin{array}{c}\text { Enquadramento } \\
\text { (zona) } \\
\text { ANP 2018 (*) }\end{array}$ & $\begin{array}{c}\text { Número de } \\
\text { Municípios }\end{array}$ & $\begin{array}{c}\text { Receitas de } \\
\text { Royalties e } \\
\text { PE (1) }\end{array}$ & $\begin{array}{c}\text { Total Geral das } \\
\text { Receitas Líquidas } \\
\text { Realizadas (2) }\end{array}$ & $\begin{array}{c}\text { População } \\
\mathbf{2 0 1 8} \\
\text { (mil hab.) }\end{array}$ & $\begin{array}{c}\text { R\&PE per } \\
\text { capita } \\
\text { (R\$/hab.) }\end{array}$ & $\begin{array}{c}\text { Grau de } \\
\text { dependência } \\
\text { (1/2) }\end{array}$ \\
\hline $\begin{array}{l}\text { Zona de Produção } \\
\text { Principal }\end{array}$ & 18 & $6.209 .248,8$ & $44.952 .907,4$ & 10.036 & 618,7 & $13,8 \%$ \\
$\begin{array}{l}\text { Zona de Produção } \\
\text { Secundária }\end{array}$ & 4 & $137.315,1$ & $1.019 .669,3$ & 384 & 358,0 & $13,5 \%$ \\
$\begin{array}{l}\text { Zona limítrofe } \\
\text { Não enquadrados }\end{array}$ & 65 & $1.009 .012,5$ & $15.082 .351,0$ & 6.575 & 153,5 & $6,7 \%$ \\
$\quad$ & 5 & $12.240,7$ & $553.281,9$ & 165 & 74,3 & $2,2 \%$ \\
\hline \multicolumn{1}{c}{ Total } & $\mathbf{9 2}$ & $\mathbf{7 . 3 6 7 . 8 1 7 , 0}$ & $\mathbf{6 1 . 6 0 8 . 2 0 9 , 6}$ & $\mathbf{1 7 . 1 6 0}$ & $\mathbf{4 2 9 , 4}$ & $\mathbf{1 2 , 0 \%}$ \\
\hline
\end{tabular}

(1) Inclui Royalties até 5\% e excedentes (1.7.21.22.30.00 e 1.7.21.22.40.00); Participações Especiais (1.7.21.22.50.00); Fundo Especial do Petróleo - FEP (1.7.21.22.70.00) e a cota-Parte de $25 \%$ dos Royalties até $5 \%$ recebidos pelos Estados (1.7.22.22.30.00).

(2) Receitas realizadas brutas - deduções das receitas - dedução para formação do Fundeb.

Como se pode observar, o grau de dependência das rendas do petróleo e gás é mais elevado que a média estadual (12\%) para os conjuntos dos 18 municípios que integram a zona de produção principal e dos 4 enquadrados como zona de produção secundária - grupos que são beneficiados pelos critérios de distribuição das rendas, já discutidos. Para os demais 70 municípios, o peso das rendas (médias apuradas) é menos significativo, ainda que a análise agregada possa encobrir distintas realidades.

Por essa razão, buscando maior acuidade na análise da situação dos municípios mais dependentes, a Tabela 5 apresenta o grau de dependência e as receitas do petróleo e gás, por habitante, em 2018, dos municípios enquadrados pela ANP nas zonas de produção principal e secundária.

Tabela 5. Grau de Dependência e rendas petrolíferas per capita, Municípios do RJ enquadrados nas Zonas de Produção Principal e Secundária - 2018 (em mil reais correntes) Fonte: SIOPS/MS. www.siops.datasus.gov.br. ANP e IBGE (população).

\begin{tabular}{lcr}
\hline \multicolumn{1}{c}{ Municípios } & $\begin{array}{c}\text { Grau de Dependência 2018 } \\
\text { (R\&PE (1)/Receitas Totais } \\
\text { líquidas (2)) }\end{array}$ & $\begin{array}{c}\text { R\&PE } \\
\text { per capita }\end{array}$ \\
\hline Maricá & Zona de Produção Principal & $9.104,7$ \\
Arraial do Cabo & $73 \%$ & $2.363,1$ \\
Parati & $47 \%$ & $2.848,4$ \\
Quissamã & $47 \%$ & $4.064,8$ \\
São João da Barra & $41 \%$ & $4.749,2$ \\
Carapebus & $41 \%$ & $2.799,5$ \\
Niterói & $40 \%$ & $2.504,7$ \\
Campos dos Goytacazes & $38 \%$ & $1.402,3$ \\
Rio das Ostras & $35 \%$ & $1.460,4$ \\
Armação dos Búzios & $33 \%$ & $2.483,8$ \\
Casimiro de Abreu & $32 \%$ & $2.049,5$ \\
Saquarema & $32 \%$ & $1.202,2$ \\
Cabo Frio & $30 \%$ & 932,2 \\
Macaé & $28 \%$ & $2.569,4$ \\
Angra dos Reis & $26 \%$ & 750,1 \\
Itaguaí & $13 \%$ & 517,6 \\
Duque de Caxias & $12 \%$ & 152,6 \\
\hline
\end{tabular}




\begin{tabular}{lcr}
\hline Rio de Janeiro & $2 \%$ & 86,4 \\
\hline Magé & Zona de Produção Secundária & \\
Guapimirim & $8 \%$ & 175,5 \\
Silva Jardim & $22 \%$ & 647,5 \\
Cachoeiras de Macacu & $19 \%$ & $1.154,1$ \\
& $16 \%$ & 526,4 \\
\hline
\end{tabular}

(1) Inclui Royalties até 5\% e excedentes (1.7.21.22.30.00 e 1.7.21.22.40.00); Participações Especiais (1.7.21.22.50.00); Fundo Especial do Petróleo - FEP (1.7.21.22.70.00) e a cota-Parte de $25 \%$ dos Royalties até $5 \%$ recebidos pelos Estados (1.7.22.22.30.00).

(2) Receitas realizadas brutas - deduções das receitas - dedução para formação do Fundeb.

Mesmo dentre os municípios mais beneficiados, é possível perceber os distintos graus de dependência que os orçamentos apresentam das rendas petrolíferas.

Maricá, hoje o principal beneficiado pela proximidade com o campo de Lula (maior produtor nacional, como mencionado), apresenta uma dependência de expressivos $73 \%$. Isso quer dizer que $\mathrm{R} \$ \mathbf{7 , 3}$ de cada $\mathrm{R} \$$ 10 do orçamento municipal de 2018 (receitas líquidas) foram provenientes da exploração do petróleo e gás natural, resultando em um valor superior a $\mathrm{R} \$ 9,1$ mil para cada um dos 158 mil habitantes naquele ano.

Embora enquadrado na mesma zona e sendo o 5o município que mais recebeu receitas do petróleo e gás, o Rio de Janeiro - capital estadual, que conta com outras fontes relevantes de receitas próprias e de transferências - apresentou uma dependência inexpressiva, sendo apenas $2 \%$ do orçamento provenientes da exploração dos recursos naturais. O valor recebido em 2018 (R\$ 578 milhões), se dividido por seus 6,6 milhões de habitantes, representaria R\$ 86 per capita, bem menos que o valor que teria sido recebido pelos habitantes de Maricá. Tanto o grau de dependência como a receita per capita ficaram muito abaixo das médias do conjunto dos municípios da zona de produção principal $(13,8 \%$ e $R \$ 618,7)$ e do conjunto dos 92 municípios do estado $(12 \%$ e $R \$ 429,4)$, respectivamente, como apurado na Tabela 4.

Niterói, Campos dos Goytacazes e Macaé também figuram entre os municípios mais beneficiados, apesar de apresentarem diferentes graus de dependência (38\%, 35\% e 26\%, respectivamente) e de rendas por habitante (de pouco mais de $\mathrm{R} \$ \mathbf{2 . 5 0 0}$ em Niterói e Maricá, cidades que possuem receitas próprias significativas, e R\$ 1.402 em Campos, tradicional beneficiário, cujos orçamentos sempre apresentaram elevada dependência desses recursos).

Também entre os municípios da zona de produção secundária é possível observar níveis de dependência e de receitas por habitante bastante variáveis. Magé, por exemplo, registrou uma receita per capita de royalties e PE de apenas R\$ 175 por habitante, enquanto em Silva Jardim essa mesma receita somou $R \$ 1.154$ por habitante; nas 2 cidades, o grau de dependência também foi bastante distinto, de $8 \%$ em Magé, e 19\% em Silva Jardim. 
Estes indicadores fornecem importantes medidas a serem consideradas pelas administrações municipais em seu planejamento, visando assegurar a continuidade das políticas públicas, sob pena de graves prejuízos às populações ali residentes.

\section{Perspectivas futuras: A judicialização da distribuição das participações governamentais}

A nova legislação aprovada reflete o que foi acordado no Congresso Nacional após acirrada disputa política quanto às novas regras para a distribuição das participações governamentais do petróleo e a aplicação desses recursos.

Como mencionado, representantes de alguns dos estados produtores, insatisfeitos com o novo marco regulatório, ajuizaram ações diretas de inconstitucionalidade perante o STF, alegando violação ao pacto federativo, ao ato jurídico perfeito, ao direito adquirido, à segurança jurídica e ao princípio da isonomia, contra as novas regras de distribuição dos royalties e da participação especial introduzidas pela lei no 12.734/2012.

O governo do estado do Rio de Janeiro ajuizou a Ação Direta de Inconstitucionalidade (ADI) no 4917 no mesmo dia da entrada em vigor da lei no 12.734: 15 de março de 2013. No mérito, foi pedida a declaração de inconstitucionalidade de artigos das leis no $12.351 / 10$ e $n$ ㅇ 9.478/97, com a redação dada pela lei $n$ o $12.734 / 12^{35}$, e subsidiariamente, pedido para que as novas regras sejam aplicadas apenas a contratos celebrados após a vigência da lei no $12.734 / 12$.

O governo estadual também requereu a concessão de medida cautelar (art. 10, §3ำ da lei no 9.868/99), alegando a plausibilidade do conjunto de teses jurídicas sustentadas e a presença do periculum in mora, em razão da gravidade e da irreparabilidade dos danos.

Em síntese, o governo estadual argumenta que a nova repartição das receitas do petróleo viola a natureza compensatória das participações instituídas pelo art. 20, $\$ 1$ o da CF/88, as quais constituem receita pública originária dos estados e dos municípios produtores.

Isso porque, como já mencionado, pela interpretação gramatical do referido artigo constitucional, foi assegurado aos estados em que há produção de petróleo em seu território, plataforma continental, mar territorial ou zona econômica exclusiva, participação no resultado da exploração ou compensação financeira. Também a interpretação teleológica do art. 20, §1으 da CF/88, sugere que a sua função é compensar os estados pelos impactos ambientais e socioeconômicos da atividade petrolífera.

\footnotetext{
35 No mérito, foi pedida a declaração de inconstitucionalidade dos arts 42-B e 42-C da lei no 12.351/10 (distribuição no regime de partilha); e dos arts. 48, II; 49, II; 49-A; 49-B; 49-C, 50; 50-A; 50-B; 50-C; 50-D e 50-E da lei no 9.478/97 (distribuição no regime de concessão), com a redação dada pela lei no $12.734 / 12$.
} 
O governo do RJ alega ainda que a legislação questionada fere o equilíbrio do pacto federativo originário, que compensa os estados pela perda de ICMS referente à circulação do óleo. Com efeito, foi instituída, na Constituição, imunidade tributária sobre a remessa de petróleo, seus derivados e energia elétrica para outros estados pelo estado produtor (art. 155, §2ㅇ, X, “b”, da CF/88).

Assim, seguindo uma interpretação sistemática dos dispositivos constitucionais, entende-se que na medida em que o estado produtor deixa de arrecadar o imposto que seria devido tratando-se de qualquer outra mercadoria em circulação, o legislador originário teria estabelecido o pagamento de compensação financeira por meio dos royalties e da participação especial.

Por sua vez, a Advocacia Geral da União (AGU) alega que o fato da Constituição ter reconhecido a titularidade dos recursos minerais, inclusive os do subsolo, à União, e não ao Estado ou Município em que estão situados, harmoniza-se com os objetivos traçados em seu artigo $3^{\circ}$, para que tais recursos contribuam para o desenvolvimento de toda a nação, para a erradicação das diferenças regionais e para a promoção do bem de todos, sem qualquer tipo de discriminação.

Alega, além disso, que o art. 20, §1ํ da CF/88 não confere exclusividade ou integralidade no recebimento das compensações financeiras, mas apenas assegura o recebimento pelos estados e municípios produtores, o que continua assegurado pela lei no 12.734/12. Isso porque os estados e municípios onde há a exploração continuam sendo contemplados com alíquotas de R\&PE próprias, mas somente em outro percentual.

Ademais, os demais estados e municípios (não produtores) já recebiam participações governamentais desde a promulgação da lei no 9.478/97, conforme a redação original do art. 49, II, "e", por meio da constituição de um Fundo Especial. Ou seja, a lei no 12.734/12 não inova no ordenamento, mas apenas promove a mera alteração de percentual das alíquotas.

Por fim, a AGU refuta o argumento de que o art. 20, $\S 1^{\circ}$, da Constituição deva ser interpretado em conjunto com o art. 155, $\S 2^{\circ}$, inciso X, alínea "b", numa espécie de pacto informal ajustado durante os debates da Assembleia Nacional Constituinte, na medida em que a produção de petróleo e gás natural no país vivenciou um desenvolvimento extraordinário, principalmente, após a descoberta do pré-sal.

Não obstante a complexidade do tema e a relevância política da ação, em decisão proferida em 18 março de $2013^{36}$, a Exma. Sra. Ministra Relatora Carmem Lúcia concedeu medida liminar suspendendo os efeitos dos artigos da lei $n=9.478 / 97$ alterados pela lei $n=12.734 / 12^{37}$, que modificavam a forma de

\footnotetext{
36 Disponível em: https://goo.gl/Mb4rgB.

37 Artigos 48, II; 49, II; 49-A; 49-B; 49-C; 50, § 2ㅇ; 50-A; 50-B; 50-C; 50-D; 50-E da Lei

no 9.478/1997, com as alterações promovidas pela Lei no 12.734/2012.
} 
distribuição dos royalties e das participações especiais no regime de concessão quando a lavra ocorrer na plataforma continental, reconhecendo a presença do periculum in mora, uma vez que o pagamento de R\&PE ocorre mensalmente e, considerando que o novo diploma alteraria os contratos já em vigor, levaria ao comprometimento do orçamento em vigor dos entes federativos que teriam sua participação diminuída, podendo afetar, assim, a prestação de serviços essenciais desses estados e municípios.

Em suma, e conforme apontado anteriormente, no caso da exploração por concessão em plataforma continental continuam valendo os critérios "antigos" das leis nos 7.990/89 e 9.478/97 até a decisão final do STF.

No caso da lavra em terra, foram suspensos os efeitos dos artigos que alteravam a distribuição das participações especiais, permanecendo válida apenas a alteração promovida na destinação dos royalties excedentes da União, que foram direcionados ao Fundo Social em vez de ao Ministério da Ciência e Tecnologia.

A mesma decisão judicial também suspendeu os efeitos dos artigos da lei № 12.734/12 ${ }^{38}$, que preveem a distribuição dos royalties no regime de partilha tanto quando a produção ocorrer em terra quanto na plataforma continental.

No vácuo, então, de uma legislação regulamentadora para os contratos de partilha, nos quais incidem royalties com alíquota de $15 \%$, até a decisão do STF, só estão válidos os antigos critérios de distribuição da concessão.

Após mais de seis anos de vigência da medida cautelar, o atual Presidente do STF, Ministro Dias Toffoli, incluiu a ADI no 4917 na pauta de julgamento do dia 20 de novembro de 2019, já havendo, entretanto, pedido encaminhado pelo governo do RJ, para suspensão por seis meses da tramitação da ADI, conforme já mencionado.

Diante do quadro vigente, portanto, os municípios que apresentam elevada dependência das rendas petrolíferas e que as utilizam para financiar despesas correntes deverão promover reformas estruturais na forma de financiamento das suas atividades ou estarão sujeitos a uma verdadeira calamidade financeira com a entrada em vigor da lei no 12.734/12.

\section{CONSIDERAÇÕES FINAIS}

Este artigo buscou evidenciar a relevância das rendas do petróleo e gás natural para os orçamentos públicos dos municípios brasileiros, em especial, pela magnitude dos valores recebidos, dos municípios do RJ.

${ }^{38}$ Artigos 42-B e 42-C da Lei № 12.351/2010, introduzidos pela Lei № 12.734/2012. 
O levantamento do grau de dependência dos municípios, em especial daqueles enquadrados nas zonas de produção principal e secundária, teve por objetivo alertar para os riscos associados à dependência que os orçamentos apresentam de recursos naturais que são finitos, não renováveis, que pagam participações governamentais marcadas pela incerteza.

Além das mudanças na produção e exploração, ditadas pela lógica da atividade industrial petrolífera, também as mudanças na legislação que rege a distribuição das rendas entre os entes federativos, ampliam a incerteza quanto ao recebimento das rendas geradas e potencializam os riscos para os governos locais.

Como se analisou, a expectativa é de continuidade de priorização de investimentos das empresas petrolíferas no pré-sal da Bacia de Santos nos próximos anos, em detrimento de áreas produtoras tradicionais da Bacia de Campos, em função da elevada produtividade dos campos do pré-sal.

Confirmado esse cenário, os municípios das regiões geograficamente confrontantes deverão seguir sendo afetados, tanto em seus orçamentos - com reflexos que poderão ser positivos ou negativos a depender de eventual mudança nas regras de distribuição e nas áreas de exploração - como no que diz respeito ao estabelecimento de empresas petrolíferas e fornecedores de bens e serviços em seus territórios e seus impactos sobre o emprego e a renda. ${ }^{39}$

Some-se a esse aspecto estrutural, o fato dos novos critérios de rateio aprovados em 2012, promovendo a redistribuição de recursos para todos os estados e municípios do país, o que infligiria graves prejuízos ao RJ, estarem com seus efeitos suspensos pelo STF em 2013, em função de ações diretas de inconstitucionalidade ajuizadas por alguns estados produtores, insatisfeitos com o novo marco regulatório.

A decisão definitiva só deverá ser dada após julgamento pelo plenário do STF, previsto para ocorrer no mês de novembro de 2019, já havendo movimentação dos estados produtores, encabeçados pelo governo do RJ, solicitando o adiamento para 2020, buscando conciliação entre os estados e o Distrito Federal.

Se aprovadas as novas regras, as parcelas de royalties e participações especiais destinadas, no modelo de concessão vigente, aos estados confrontantes e municípios confrontantes e afetados ou com instalações de embarque e desembarque serão substancialmente reduzidas, enquanto deverão aumentar as parcelas dos fundos especiais, destinados a todos os estados e municípios, e do Fundo Social da União, tanto no modelo de partilha como no de concessão, direcionando ainda a aplicação das rendas às áreas de saúde e educação.

Estimativa divulgada pela Federação das Indústrias do Estado do Rio de Janeiro (Firjan), com base em estudo feito pela Secretaria de Fazenda do Estado do Rio de Janeiro, alerta para um "colapso nas contas públicas das cidades e do governo estadual" com as novas regras de rateio, mudança que acarretaria perdas

39 PIQUET et al (2017) analisam os impactos na região. 
de receitas de $\mathrm{R} \$ 30,1$ bilhões aos municípios fluminenses e de $\mathrm{R} \$ \mathbf{2 5 , 7}$ bilhões ao governo estadual nos próximos quatro anos, equivalente a $\mathrm{R} \$ 14$ bilhões anuais. ${ }^{40}$

Além da possibilidade concreta da mudança das regras de distribuição, as características próprias das rendas petrolíferas resultam em incertezas adicionais e impõem que as administrações estejam preparadas para lidar com perdas acentuadas e repentinas de recursos, e com os efeitos negativos que podem advir sobre as políticas públicas - especialmente aquelas relacionadas à gestão urbana e às áreas sociais, como a educação e a saúde, que são de responsabilidade dos municípios e que afetam diretamente a vida da população.

O acompanhamento e a necessária revisão das políticas e seus efeitos, fundamentada em evidências, com a eventual correção de rumos, são cruciais para que os governos locais proponham e implementem políticas de consequências efetivas, voltadas para o enfrentamento dos desafios trazidos pela chamada "maldição dos recursos naturais", caracterizada pela "relação negativa entre abundância de recursos naturais e nível de desenvolvimento econômico"

\section{REFERÊNCIAS}

AFONSO, Jose R.; CASTRO, Kleber P. (2017). Financiamento da educação: questões para debate. In: Seminário Técnico Sobre Financiamento da Educação Básica no Brasil - BID e Ministério da Educação, 2017, São Paulo, Anais... São Paulo: 2017. Disponível em: http://bibliotecadigital.fgv.br/dspace/handle/10438/19415.

AFONSO, Jose R.; CASTRO, Kleber P (2019). Consolidação da carga tributária bruta de 2018 (7/2019). Disponível em: https://tinyurl.com/yyy9kvmy. Acesso em: 02/09/2019.

ANP. Agência Nacional do Petróleo. (2019) Participações Governamentais Consolidadas. Disponível em: http://www.anp.gov.br/wwwanp/dados-estatisticos.

ANP. Agência Nacional do Petróleo (2019). Fonte: ANP. Anuário Estatístico 2019. Disponível em: https://tinyurl.com/y3jz3osm.

ALENCAR, André A.; GOBETTI, Sérgio W. (2008). Justiça fiscal na Federação brasileira: uma análise do sistema de transferências intergovernamentais entre 2000 e 2007. Brasília: Esaf, XIII Prêmio Tesouro Nacional. Tópicos Especiais de Finanças Públicas. BrasíliaDF.

DA CRUZ, José Luiz; TERRA, Denise C. (2015). Indústria Extrativa petrolífera fluminense e limites ao desenvolvimento regional. In: Seminário Internacional sobre Desenvolvimento Regional. Disponível em: https://tinyurl.com/y58k7zxr.

FIRJAN - Federação das Indústrias do Estado do Rio de Janeiro (2019). Royalties e Participações Especiais - impactos para o estado do Rio e seus municípios. Nota Técnica Firjan. Disponível em: https://tinyurl.com/yyqpwcab. Set/2019.

NAZARETH, Paula A. (2007). Descentralização e Federalismo Fiscal: Um Estudo de Caso dos Municípios do Rio de Janeiro. Tese (Doutorado) - Instituto de Economia, IE/UFRJ, ago. 2007. Disponível em: https://tinyurl.com/y2f96u6h.

NAZARETH, Paula A (2017). Crise econômica e capacidade de gestão local no Rio de Janeiro, Brasil. In: XXII Congresso Internacional del CLAD sobre la Reforma del Estado y de la Administración Pública, 2017, Madrid. Anais do XXII Encontro Anual del CLAD. Caracas: Centro Latinoamericano de Administracion para el desarrollo, 2017.

NAZARETH, Paula A; ARAÚJO, Nina Q.; SALLES, Jorge E. (2011). O Rio de Janeiro e o Pré-Sal: O novo marco regulatório e os impactos nas finanças do Estado e dos municípios. In: Roselia Piquet. (Org.). Mar de Riqueza, Terras de Contrastes: O petróleo no Brasil. 1ed.Rio de Janeiro: Mauad Editora Ltda, p. 179-218.

${ }^{40}$ Disponível em: https://bit.ly/2JzSdql. 
NAZARETH, Paula A; ARAUJO, Nina Q. ; OLIVEIRA, Henrique D. (2018). O Rio de Janeiro e as rendas petrolíferas: a crise e os desafios do pré-sal. In: Rosélia Piquet; Helder Queiroz Pinto Junior. (Org.). Transformações em Curso na Indústria Petrolífera Brasileira. 1ed.Rio de Janeiro: E-papers Serviços Editoriais Ltda., 2018, v. 1, p. 161-231.

SANTOS, Angela P.; NAZARETH, Paula A. Crise fiscal e seus impactos nas relações interfederativas: o caso dos municípios fluminenses. In: Santos, Angela Penalva et al (Org.). Rio de Janeiro: Uma abordagem dialógica sobre o território fluminense. Rio de Janeiro: EdUERJ, 2018. p.63-93. (Disponível em: Geo Uerj, n. 31, p. 1-33, 2017. doi:10.12957/geouerj.2017.32055.https://goo.gl/JxwgMo).

PIQUET, Rosélia; TAVARES, Erica; PESSÔA, João M. (2017). Emprego no setor petrolífero: dinâmica econômica e trabalho no Norte Fluminense. Cadernos Metrópole., v. 19, n. 38, p. 201-224, 2017. Disponível em https://goo.gl/AoqV8L. Acesso em: 05/09/17.

PRADO, Sérgio. (2001). Transferências Fiscais e Financiamento Municipal no Brasil. Trabalho elaborado para o projeto Descentralização Fiscal e Cooperação Financeira Intergovernamental. São Paulo: EBAP/K. Adenauer, jul. 2001. 